\title{
Pengaruh Parameter Pemotongan dan Variasi Susunan Serat Terhadap Terbentuknya Delaminasi pada Proses Menggurdi Material Komposit Serat Nanas
}

\author{
Bambang Dwi Haripriadi ${ }^{a}$, Ismet Hari Mulyadi ${ }^{b}$ \\ ${ }^{a}$ Mahasiswa S2 Teknik Mesin Jurusan Teknik Mesin Universitas Andalas, Kampus Unand Limau Manis, Padang 25163, Indonesia \\ ${ }^{b}$ Jurusan Teknik Mesin Fakultas Teknik Universitas Andalas, Kampus Unand Limau Manis, Padang 25163, Indonesia
}

INFORMASI ARTIKEL

\section{Sejarah Artikel:}

Diterima Redaksi: 15 Desember 2018

Revisi Akhir: 22 Maret 2018

Diterbitkan Online: 26 April 2018

\begin{tabular}{l} 
KATA KUNCI \\
\hline delamination \\
drilling \\
pine-apple \\
fiber \\
arrangement \\
KORESPONDENSI \\
\hline
\end{tabular}

E-mail: ismet@ft.unand.ac.id

\begin{abstract}
A B S T R A C T
Delamination is a failure occured during hole-making processes in machining. This can affect to rejection of the product. This failure is commonly found when drilling low machinability of plastic-based materials such as thermoplastic composites. Therefore, to eliminate that phenomena, the materials are necessary to be reinforced. In this case, addition of the fiber can strengthen the composites. Besides, the way the fibers were arranged when composite manufacturing is also responsible to improve tensile strength of the composites. Improving tensile strength would also improve the shear strength of the material. Shear strength is normally adopted as indicator for machinability of materials. However, relation of shear strength improvement of composites due to fiber arrangement has been rarely discussed. Using orthogonal arrays L27 based on Taguchi, this study investigated the effect fiber arrangement on formation of delamination in drilling pine-apple leaves reinforced composites. The results highlighted that effect fiber arrangement was significant on formation of delamination at exit sides of drilled holes. Reduced rasio delamination had been identified at this side. This inferr that strengthening effect would be a good strategy in reducing delamination at the exit sides.
\end{abstract}

\section{PENDAHULUAN}

Kom posit merupakan jenis material yang telah dipergunakan secara luas yang disebabkan karena kemampuan beradaptasi dengan kondisi yang berbeda-beda, mudah dalam penggabungan sehingga menghasilkan sifat yang diinginkan. Umumnya produk-produk diproduksi dengan mempergunakan material komposit ini berupa panel-panel yang masih membutuhkan proses lanjutan (secondary process) untuk perakitannya. Untuk proses perakitan dapat dilakukan dengan mempergunakan lem (adhesive) ataupun secara mekanik dengan mempergunakan baut atau keling (rivet).[1]

Pada proses perakitan dengan mempergunakan baik dengan baut maupun keling (rivet) dibutuhkan lubang sebelum proses dilakukan. Yang mana proses menggurdi (drilling), pada umumnya men- 
jadi pilihan utama [2]. Akan tetapi proses pembuatan lubang pada material komposit dengan mempergunakan proses menggurdi masih menghadapi kendala dimana $60 \%$ dari produk yang dihasilkan menunjukkan kualitas yang rendah [3].

Kualitas rendah dari lubang yang dihasilkan akan berimbas kepada penurunan kekuatan dan umur lelah (fatigue strength) dari produk yang dihasilkan [4]. Penurunan kekuatan yang disebabkan oleh kualitas lubang yang rendah dan panas yang timbul selama proses pemotongan menyebabkan mekanisme geser (shearing) akan diambil alih oleh mekanisme bajak (ploughing).

Mekanisme ploughing ini menyebabkan proses terbentuknya geram terjadi melalui deformasi plastis sehingga ada bagian geram (chips) yang tidak putus tetapi menumpuk pada permukaan lubang. Penumpukan geram (chips) pada permukaan geram ini disebut delaminasi dan terjadi baik pada lubang sisi masuk (entrance) maupun sisi keluar (exit). Hal ini menjadi perhatian utama pada proses menggurdi material komposit dengan penguat serat (fiber-reinforced plastic composite) dan penting untuk dihindari [5].

Serat daun nanas (pineapple-leaf fibres) adalah salah satu jenis serat yang berasal dari tumbuhan (vegetable fibre) yang diperoleh dari daun-daun tanaman nanas. Tanaman nanas merupakan tumbuhan yang tumbuh didaerah teropis yang juga mempunyai nama lain, yaitu Ananas Cosmosus, (family Bromeliaceae) [6]. Tumbuhan nanas memiliki potensi untuk dikembangkan menjadi serat penguat untuk material komposit [7]. Akan tetapi kekuatan tarik serat nanas sebagai penguat cukup rendah $170 \mathrm{Mpa}$ [8]. Hal ini akan berdampak terhadap timbulnya delaminasi pada proses menggurdi untuk material komposit dengan penguat serat nanas.

Variasi susunan serat diyakini akan dapat meningkatkan kekuatan komposit serat nanas, tetapi dengan keterbatasan informasi tentang pengaruh variasi susunan serat terhadap terbentuknya delaminasi pada proses gurdi. Oleh karena itu, penelitian ini dilakukan dalam rangka untuk melihat sejauh mana kemampuan variasi susunan serat sebagai bahan penguat pada komposit serat nanas dapat meningkatkan kekuatan tarik sehingga dapat mempengaruhi atau memperkecil terbentuknya delaminasi pada proses menggurdi.

\section{METODOLOGI}

\subsection{Bahan dan Peralatan}

\subsubsection{Bahan}

A. Bahan spesimen

Untuk penelitian ini digunakan spesimen dari material komposit dengan jenis termoplastik (polyvinil asetat) yang berbentuk persegi panjang dengan ukuran diameter $100 \mathrm{~mm}$ x $50 \mathrm{~mm}$ x $5 \mathrm{~mm}$. Spesimen ini terdiri dari 3 lapisan yang setiap lapisan terdapat penguat dari serat nenas dengan bentuk variasi susunan serat yaitu crossed, multidirectional dan continuous strandmat (CSM) (Gambar 1). Dengan jarak antara serat dibuat dengan jarak $1 \mathrm{~mm}$ terlihat pada Gambar 2.

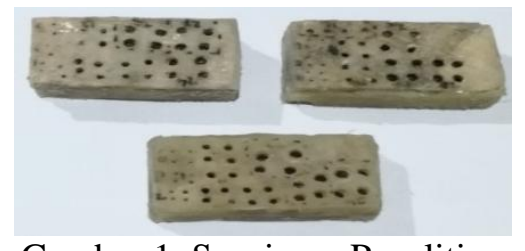

Gambar 1. Spesimen Penelitian

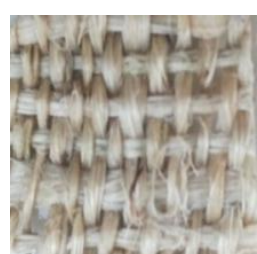

(a)

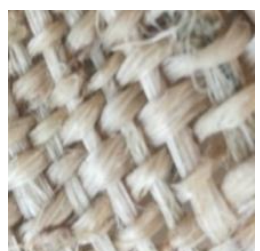

(b)

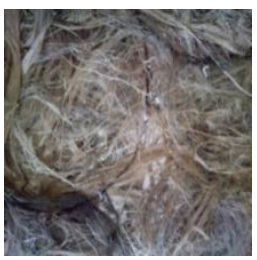

(c)
Gambar 2. Variasi Susunan Serat Nanas Jenis (a) Crossed, (b) Multidirectional, dan (c) Continuous strandmat (CSM)

B. Bahan cairan pendingin.

Bahan pendingin pada penelitian ini dimaksud untuk pendingin pada proses permesinan gurdi, adapun bahan yang digunakan terdiri atas 3 jenis yaitu:

1. Udara yang digunakan sebagai bahan pendingin yang disemprotkan melalui mesin kompresor langsung kepermukaan material dan pahat pada proses menggurdi.

2. Cairan Sintetis yang dipergunakan adalah jenis Dromus yang disemprotkan langsung ke daerah pemotongan pertemuan antara pahat dan benda kerja yang terpotong (Jet Application of Fluid) [15].

3. Minyak Kelapa Sawit (Minyak goreng curah)

C. Pahat gurdi.

Pahat gurdi yang digunakan adalah jenis twist drill dengan diameter $2 \mathrm{~mm}, 4 \mathrm{~mm}$ dan $6 \mathrm{~mm}$ yang ter- 
buat dari material high speed steel (HSS) yang dilapisi dengan kobalt seperti terlihat pada Gambar 3.

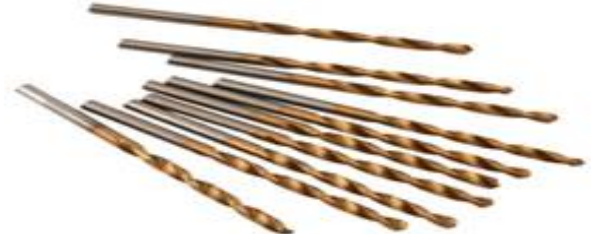

Gambar 3. Pahat Gurdi HSS Cobalt Coating jenis Twist Drill

\subsubsection{Peralatan}

Pada penelitian ini, untuk menghasilkan lubang dipergunakan Mesin CNC Emco Concept MILL 55 (Gambar 4). Mesin ini dipilih karena sistem kerjanya yang dilengkapi sistem mekanik dan kontrol yang berbasis computer yang dilengkapi dengan kode $\mathrm{G}$ ( $G$ Code) sehingga lebih mudah dalam mengatur parameter pemesinan seperti speed dan feeding dan kedalaman potong. Disamping itu kepresisian, kestabilan dan kesimetrisan hasil pemesinan dapat diharapkan dengan mempergunakan mesin ini.

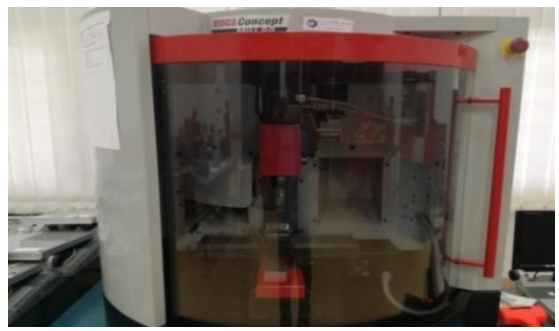

Gambar 4. Mesin CNC Milling (Mill 55)

Sedangkan untuk mengamati dan mengukur besarnya delaminasi dipergunakan mikroskop microcapture yang yang dilengkapi dengan kamera serta perangkat lunak pengukuran Microcapture Veho Vms 004. Mikroskop yang dipergunakan diperlihatkan pada Gambar 5.

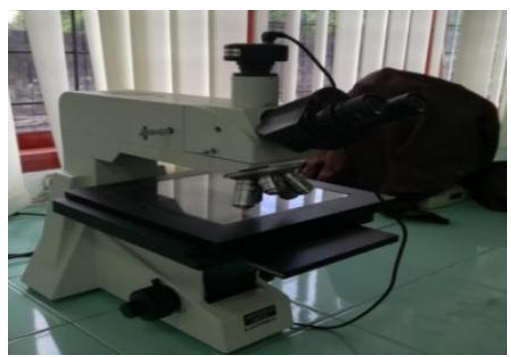

Gambar 5. Mikroskop

\subsubsection{Metoda Pengukuran}

Pengukuran dilakukan pada permukaan lubang hasil menggurdi baik pada bagian atas maupun bawah. Pengukuran permukaan objek dilakukan secara visual di layar komputer menggunakan program Microcapture Veho Vms 004. Kemudian delaminasi diukur dengan mengukur diameter lubang hasil gurdi (D) dan diameter delaminasi $\left(D_{\max }\right)$ yang dihasilkan dari proses menggurdi (Gambar 6). Sedangkan hasil pengukuran diperoleh dengan melakukan pengukuran sebanyak 10 titik sekeliling lubang dan daerah delaminasi (Gambar 7) yang terbentuk. Kemudian diambil nilai rata-ratanya berdasarkan Persamaan (1) [9], dimana $\mathrm{D}_{\max }$ (dalam $\mathrm{mm}$ ) adalah ukuran diameter akibat delaminasi dan $\mathrm{D}$ (dalam $\mathrm{mm}$ ) adalah ukuran diameter lubang yang dihasilkan proses menggurdi.

$$
F d=\left(D_{\text {Max }}\right) / D
$$

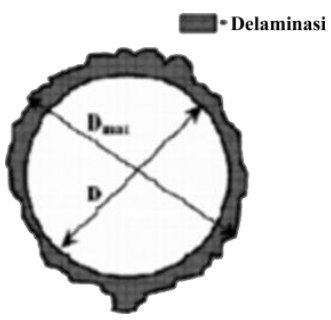

Gambar 6. Skema Pengukuran Delaminasi [9]

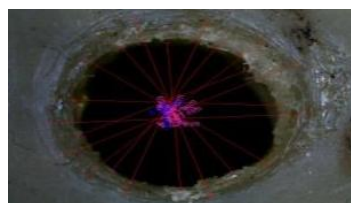

(a)

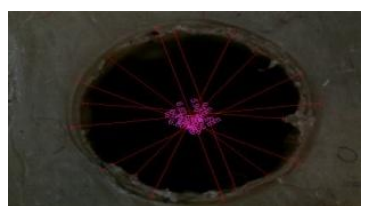

(b)
Gambar 7. Pengukuran Delaminasi pada hasil gurdi, (a) pada sisi Entrance, (b) pada sisi Exit 2.1.4. Rancangan Penelitian

Pada penelitian ini dipilih rancangan dengan sususunan Orthogonal array Desain Taguchi dengan metoda statis. Metoda ini dipilih disebabkan kemampuannya dalam mengurangi jumlah percobaan dan menunjukkan kemungkinan interaksi. Dalam pemilihan susunan orthogonal tergantung pada jumlah faktor atau parameter yang diamati dan jumlah tingkat atau level dari setiap faktor.

Selanjutnya, berdasarkan 5 faktor yang diamati dengan 3 tingkatan untuk setiak faktornya, maka dipilihan susunan orthogonal L27. Adapun faktor dan levelnya diperlihatkan pada Tabel 1. 
Tabel 1. Faktor dan Level untuk L27

\begin{tabular}{clccc}
\hline ID. & \multicolumn{1}{c}{ Faktor } & Level 1 & Level 2 & Level 3 \\
\hline A & Diameter tool & $2 \mathrm{~mm}$ & $4 \mathrm{~mm}$ & $6 \mathrm{~mm}$ \\
B & Feding $(\mathrm{mm} / \mathrm{rev})$ & 0.084 & 0.168 & 0.336 \\
C & Sudut ujung $\left(2 \kappa_{\mathrm{r}}{ }^{\circ}\right)$ & $70^{\circ}$ & $110^{\circ}$ & $140^{\circ}$ \\
D & $\begin{array}{l}\text { Susunan serat nenas } \\
\text { (Continuous) }\end{array}$ & Crossed & multi & CSM \\
E & Pendinginan & Udara & Sintesis & $\begin{array}{c}\text { Minyak } \\
\text { goreng }\end{array}$ \\
\cline { 2 - 5 } & & & &
\end{tabular}

Berdasarkan pemilihan parameter pada Tabel 1., maka kombinasi susunan Orthogonal array L27. 27 diperlihatkan pada Tabel 2. Masing-masing kombinasi ini dilakukan secara berulang (repetition) sebanyak 2 kali untuk mengukur sebanyak 6 lubang untuk setiap kombinasi. Dengan pengulangan sebanyak 2 kali, maka kombinasi akan menjadi berjumlah 54 kombinasi. Seluruh kombinasi ini akan diacak dengan mempergunakan random generator. Hasil pengacakan akan dipergunakan sebagai tahapan dalam pengambilan data.

Tabel 2. Susunan Orthoghonal Array L27

\begin{tabular}{c|ccccc}
\hline & & \multicolumn{4}{c}{ L27 $\left(3^{5}\right)$} \\
\cline { 2 - 6 } No & $\begin{array}{c}\text { Dia. } \\
\text { Pahat } \\
(\mathrm{mm})\end{array}$ & $\begin{array}{c}\text { Feeding } \\
(\mathrm{mm} / \mathrm{rev})\end{array}$ & $\begin{array}{c}\text { Sudut } \\
\text { Ujung } \\
\left(2 \kappa_{\mathrm{r}}\left(^{\circ}\right)\right)\end{array}$ & $\begin{array}{c}\text { Susunan } \\
\text { Nanas }\end{array}$ & Pendingin \\
\hline 1 & 2 & 0.084 & 70 & Crossed & Udara \\
2 & 2 & 0.084 & 70 & Crossed & Sintetis \\
3 & 2 & 0.084 & 70 & Crossed & Minyak \\
4 & 2 & 0.168 & 110 & Multi & Udara \\
5 & 2 & 0.168 & 110 & Multi & Sintetis \\
6 & 2 & 0.168 & 110 & Multi & Minyak \\
7 & 2 & 0.336 & 140 & CSM & Udara \\
8 & 2 & 0.336 & 140 & CSM & Sintetis \\
9 & 2 & 0.336 & 140 & CSM & Minyak \\
10 & 4 & 0.084 & 110 & CSM & Udara \\
11 & 4 & 0.084 & 110 & CSM & Sintetis \\
12 & 4 & 0.084 & 110 & CSM & Minyak \\
13 & 4 & 0.168 & 140 & Crossed & Udara \\
14 & 4 & 0.168 & 140 & Crossed & Sintetis \\
15 & 4 & 0.168 & 140 & Crossed & Minyak \\
16 & 4 & 0.336 & 70 & Multi & Udara \\
17 & 4 & 0.336 & 70 & Multi & Sintetis \\
18 & 4 & 0.336 & 70 & Multi & Minyak \\
19 & 6 & 0.084 & 140 & Multi & Udara \\
20 & 6 & 0.084 & 140 & Multi & Sintetis \\
21 & 6 & 0.084 & 140 & Multi & Minyak \\
22 & 6 & 0.168 & 70 & CSM & Udara \\
23 & 6 & 0.168 & 70 & CSM & Sintetis
\end{tabular}

\begin{tabular}{rrrrrc}
24 & 6 & 0.168 & 70 & CSM & Minyak \\
25 & 6 & 0.336 & 110 & Crossed & Udara \\
26 & 6 & 0.336 & 110 & Crossed & Sintetis \\
27 & 6 & 0.336 & 110 & Crossed & Minyak \\
\hline
\end{tabular}

\subsubsection{Analisa Data}

Pada proses ini untuk melihat hasil proses pemesinan gurdi digunakan mikrsokop dengan kamera microcapture yang berfungsi untuk melihat dan mengambil gambar delaminasi yang terbentuk. Data dari hasil ini akan dianalisa dengan menggunakan metode $S / N$ Ratio (signal to noise ratio) dan Analysis of Variances (ANOVA). S/N Ratio (signal to noise ratio) digunakan untuk memilih kriteria parameter yang dapat meminimalkan kondisi "error variances" yang disebabkan oleh faktor -faktor yang tidak dapat dikendalikan menggunakan program Minitab 16.

\section{HASIL DAN PEMBAHASAN}

\subsection{Pengaruh Susunan Serat Nanas Terhadap Terbentuknya Delaminasi pada Sisi Masuk (Entrance) Lubang}

Pengaruh penguatan material komposit terhadap kualitas lubang yang dihasilkan telah diamati. Hasil pengukuran diamater lubang yang memiliki penumpukan material (delaminasi) yang dibagi dengan diameter lubang yang dihasilkan (Rasio delaminasi) diperlihatkan pada Tabel 3. Dari Tabel 3 diketahui bahwa diameter pahat yang besar $(6$ $\mathrm{mm})$, gerak makan yang moderat $(0,168 \mathrm{~mm} / \mathrm{r})$, sudut ujung paling kecil $\left(70^{\circ}\right)$, susunan serat Continuous strandmat (CSM), dan pemilihan cairan pendingin jenis sintetis dapat mengurangi kemungkinan terjadinya delaminasi pada permukaan lubang bagian atas (entrance). Mengacu ke data hasil pengukuran yang diperlihatkan pada Tabel 3., delaminasi pada sisi lubang bagian atas (entrance) untuk kombinasi yang tepat hanya sekitar $0,022 \mathrm{~mm}$ atau 0,2 mikron. Nilai ini sangatlah kecil.

Kondisi ini kemungkinan disebabkan penggunaan susunan serat jenis CSM yang mampu memberikan kekuatan dari material komposit. Susunan serat jenis ini dibuat secara acak. Dengan kondisi ini akan menyulitkan dislokasi terjadi sehingga kekuatan material menjadi lebih tinggi. Dengan kekuatan yang tinggi, maka akan mempengaruhi kekuatan geser dari material. Dengan kekuatan geser yang secara tidak langsung meningkat, maka pahat gurdi yang memiliki mata potong yang tidak tajam akan dapat menjalankan fungsinya untuk melakukan pergeseran sehingga dihasilkan geram. Hal ini 
disebabkan kekuatan geser dari material komposit yang sudah diperkuat memungkinkan menyebabkan mampu mesin material menjadi lebih baik. Selain itu efek pembajakan (ploughing) yang terjadi pada proses menggurdi komposit termoplastik yang lunak tidak terjadi sehingga delaminasi dapat diminimalkan.

Akan tetapi, hasil yang ditunjukkan pada Tabel 3 . belum dapat dijadikan indikator bahwa rendahnya nilai delaminasi yang terjadi disebabkan karena adanya penguatan yang dilakukan oleh susunan serat. Untuk itu, data yang diperoleh dianalisa dengan mempergunakan metoda ANOVA.

Tabel 3. Hasil pengukuran delaminasi untuk sisi masuk lubang (entrance)

\begin{tabular}{|c|c|c|c|c|c|c|}
\hline No. & $\begin{array}{l}\text { Dia. } \\
\text { Pahat } \\
(\mathrm{mm})\end{array}$ & $\begin{array}{c}\text { Feed } \\
(\mathrm{mm} / \mathrm{rev})\end{array}$ & $\begin{array}{c}\text { Sudut } \\
\text { Ujung } \\
\left(2 \kappa_{\mathrm{r}}\right) \\
\left({ }^{\circ}\right)\end{array}$ & $\begin{array}{c}\text { Susunan } \\
\text { Serat }\end{array}$ & Pendingin & $\begin{array}{c}\mathrm{Fd}_{\text {rata- }} \\
\text { rata } \\
(\mathrm{mm})\end{array}$ \\
\hline 1 & 2 & 0.084 & 70 & Crossed & Udara & 1,248 \\
\hline 2 & 2 & 0.084 & 70 & Crossed & Sintetis & 1,076 \\
\hline 3 & 2 & 0.084 & 70 & Crossed & Minyak & 1,164 \\
\hline 4 & 2 & 0.168 & 110 & Multi & Udara & 1,404 \\
\hline 5 & 2 & 0.168 & 110 & Multi & Sintetis & 1,212 \\
\hline 6 & 2 & 0.168 & 110 & Multi & Minyak & 1,360 \\
\hline 7 & 2 & 0.336 & 140 & CSM & Udara & 1,637 \\
\hline 8 & 2 & 0.336 & 140 & CSM & Sintetis & 1,193 \\
\hline 9 & 2 & 0.336 & 140 & CSM & Minyak & 1,132 \\
\hline 10 & 4 & 0.084 & 110 & CSM & Udara & 1,307 \\
\hline 11 & 4 & 0.084 & 110 & CSM & Sintetis & 1,084 \\
\hline 12 & 4 & 0.084 & 110 & CSM & Minyak & 1,144 \\
\hline 13 & 4 & 0.168 & 140 & Crossed & Udara & 1,090 \\
\hline 14 & 4 & 0.168 & 140 & Crossed & Sintetis & 1,172 \\
\hline 15 & 4 & 0.168 & 140 & Crossed & Minyak & 1,136 \\
\hline 16 & 4 & 0.336 & 70 & Multi & Udara & 1,261 \\
\hline 17 & 4 & 0.336 & 70 & Multi & Sintetis & 1,118 \\
\hline 18 & 4 & 0.336 & 70 & Multi & Minyak & 1,128 \\
\hline 19 & 6 & 0.084 & 140 & Multi & Udara & 1,236 \\
\hline 20 & 6 & 0.084 & 140 & Multi & Sintetis & 1,084 \\
\hline 21 & 6 & 0.084 & 140 & Multi & Minyak & 1,175 \\
\hline 22 & 6 & 0.168 & 70 & CSM & Udara & 1,222 \\
\hline 23 & 6 & 0.168 & 70 & CSM & Sintetis & 1,022 \\
\hline 24 & 6 & 0.168 & 70 & CSM & Minyak & 1,065 \\
\hline 25 & 6 & 0.336 & 110 & Crossed & Udara & 1,177 \\
\hline 26 & 6 & 0.336 & 110 & Crossed & Sintetis & 1,091 \\
\hline 27 & 6 & 0.336 & 110 & Crossed & Minyak & 1,136 \\
\hline
\end{tabular}

Hasil ANOVA ditampilkan pada Tabel 4. Dari hasil ANOVA terlihat bahwa faktor penguatan serat akibat susunan tidak memberikan pengaruh yang signifikan $(P \leq 0,05)$ pada tingkat keyakinan $95 \%$. Yang memiliki pengaruh signifikan pada penelitian ini adalah cairan pendingin dan diamater pahat. Hal ini dapat dipahami karena pada material komposit yang berbasiskan termoplastik yang dipergunakan pada penelitian ini, lapisan serat dipasangkan di bawah permukaan material; berjarak 1 $\mathrm{mm}$. Hal ini menyebabkan kekuatan permukaan material tidak sekuat dengan lapisan di bawahnya yang telah diperkuat. Apabila panas dari pahat tidak dengan sempurna diturunkan maka akan menyebabkan permukaan material menjadi melunak yang tergantung ukuran diameter pahat akan memicu terjadinya delaminasi.

Tabel 4. Hasil ANOVA data pengukuran delaminasi pada lubang permukaan atas (entrance)

\begin{tabular}{lcccccc}
\hline Parameter & DF & $\begin{array}{c}\text { Seq } \\
\text { SS }\end{array}$ & $\begin{array}{c}\text { Adj } \\
\text { SS }\end{array}$ & $\begin{array}{c}\text { Adj } \\
\text { MS }\end{array}$ & F & P \\
\hline $\begin{array}{l}\text { Dia. Pahat } \\
(\mathrm{mm})\end{array}$ & 2 & 0,186 & 0,186 & 0,093 & 8,28 & 0,001 \\
$\begin{array}{l}\text { Feeding } \\
(\mathrm{mm} / \mathrm{r})\end{array}$ & 2 & 0,014 & 0,014 & 0,007 & 0,62 & 0,541 \\
$\begin{array}{l}\text { Sudut ujung } \\
\left(2 \kappa_{\mathrm{r}}{ }^{\circ}\right)^{-}\end{array}$ & 2 & 0,050 & 0,014 & 0,025 & 2,23 & 0,120 \\
$\begin{array}{l}\text { Susunan } \\
\text { serat }\end{array}$ & 2 & 0,057 & 0,057 & 0,028 & 2,52 & 0,092 \\
Pendingin & 2 & 0,282 & 0,282 & 0,141 & 12,52 & 0,000 \\
$\begin{array}{l}\text { Error } \\
\text { Total }\end{array}$ & 43 & 0,484 & 0,484 & 0,011 & - & - \\
\hline
\end{tabular}

Kesimpulan yang didapat dari ANOVA ini dapat dikatakan valid. Hal ini didasari bahwa kecenderungan data yang diperoleh memiliki kecenderungan yang normal. Yang mana pengujian Normal Probability Plot (Gambar 8a), dan Residual vs fitted values (Gambar 8b) mengindikasikan bahwa seluruh data yang didapat pada penelitian ini tersebar secara merata pada garis linier perkiraan. Tidak ada outliers atau kemungkinan kesa-lahan data. Sedangkan dari Histogram nilai residual dari data (Gambar 8c) terlihat bahwa secara umum proporsional. Tidak ada kemungkinan kecenderungan miring (skewness) ataupun outliers. 


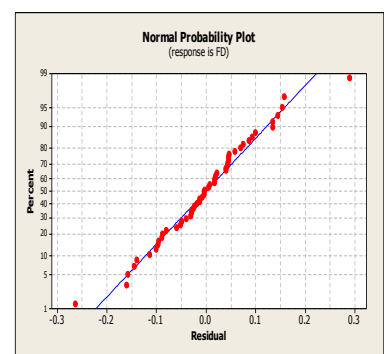

(a)

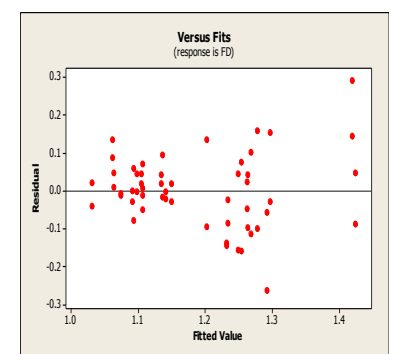

(b)

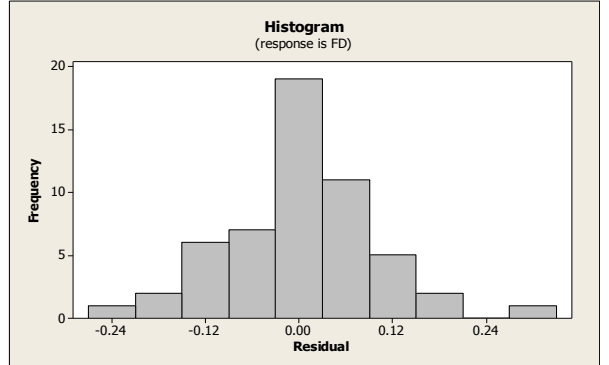

(c)

Gambar 8. Hasil Analisa Normality Data Pengujian untuk Data Delaminasi Lubang Masuk (entrance)

\subsection{Pengaruh Susunan Serat Nanas Terhadap Terbentuknya Delaminasi pada Sisi Keluar (Exit) Lubang}

Selanjutnya, untuk pengamatan terbentuknya delaminasi pada lubang keluaran (Exit) diperlihatkan pada Tabel 5. Dari Tabel 5. diketahui bahwa pada diameter pahat yang kecil $(2 \mathrm{~mm})$, gerak makan kecil $(0,084 \mathrm{~mm} / \mathrm{rev})$, sudut ujung kecil $\left(70^{\circ}\right)$ serta susunan serat nanas jenis crossed delaminasi yang terbentuk lebih kecil dibandingkan kombinasi paramater lainnya.

Tabel 5. Hasil pengukuran delaminasi untuk sisi keluar lubang (exit)

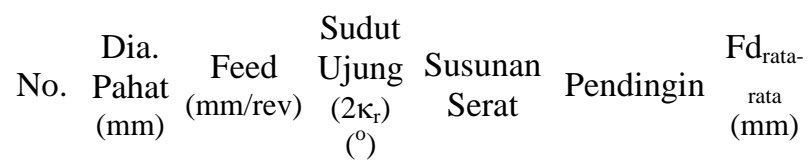

\begin{tabular}{ccccccc}
\hline 1 & 2 & 0.084 & 70 & Crossed & Udara & 1,248 \\
2 & 2 & 0.084 & 70 & Crossed & Sintetis & 1,131 \\
3 & 2 & 0.084 & 70 & Crossed & Minyak & 1,171 \\
4 & 2 & 0.168 & 110 & Multi & Udara & 1,275 \\
5 & 2 & 0.168 & 110 & Multi & Sintetis & 1,204 \\
6 & 2 & 0.168 & 110 & Multi & Minyak & 1,243 \\
7 & 2 & 0.336 & 140 & CSM & Udara & 1,473 \\
8 & 2 & 0.336 & 140 & CSM & Sintetis & 1,253 \\
9 & 2 & 0.336 & 140 & CSM & Minyak & 1,348 \\
10 & 4 & 0.084 & 110 & CSM & Udara & 1,266 \\
11 & 4 & 0.084 & 110 & CSM & Sintetis & 1,148 \\
12 & 4 & 0.084 & 110 & CSM & Minyak & 1,232
\end{tabular}

\begin{tabular}{rrrrccc}
13 & 4 & 0.168 & 140 & Crossed & Udara & 1,193 \\
14 & 4 & 0.168 & 140 Crossed & Sintetis & 1,159 \\
15 & 4 & 0.168 & 140 & Crossed & Minyak & 1,182 \\
16 & 4 & 0.336 & 70 & Multi & Udara & 1,223 \\
17 & 4 & 0.336 & 70 & Multi & Sintetis & 1,162 \\
18 & 4 & 0.336 & 70 & Multi & Minyak & 1,199 \\
19 & 6 & 0.084 & 140 & Multi & Udara & 1,230 \\
20 & 6 & 0.084 & 140 & Multi & Sintetis & 1,167 \\
21 & 6 & 0.084 & 140 & Multi & Minyak & 1,218 \\
22 & 6 & 0.168 & 70 & CSM & Udara & 1,225 \\
23 & 6 & 0.168 & 70 & CSM & Sintetis & 1,182 \\
24 & 6 & 0.168 & 70 & CSM & Minyak & 1,194 \\
25 & 6 & 0.336 & 110 & Crossed & Udara & 1,216 \\
26 & 6 & 0.336 & 110 & Crossed & Sintetis & 1,195 \\
27 & 6 & 0.336 & 110 Crossed & Minyak & 1,206 \\
\hline
\end{tabular}

Hal ini berbeda terhadap delaminasi yang rendah pada lubang masuk (entrance). Akan tetapi ada dua parameter yang tetap konstan dalam mempengaruhi pengurangan delaminasi, yaitu sudut ujung dan jenis cairan pendingain yang dipergunakan. Yang mana ujung pahat yang memiliki sudut potong runcing dan jenis cairan sintetis dapat mengurangi delaminasi pada penelitian ini. Baik itu untuk lubang masuk maupun keluar. Kondisi menunjukkan bahwa pada proses menggurdi material komposit yang diperkuat dengan serat, kemampuan "menusuk" merupakan unsur penting yang harus dipertimbangkan.

Selanjutnya, berbeda halnya dengan pada proses menggurdi bagian atas material komposit yang telah diperkuat dengan susunan serat, pada tahapan untuk membuat lubang menjadi tembus, pengaruh faktor penguat berpengaruh. Hal ini dapat dilihat dari hasil analisa ANOVA seperti pada Tabel 6 . Yang mana pemilihan cairan pendingin masih menjadi faktor yang menentukan dalam mengurangi delaminasi pada proses penyelesaian lubang (exit). Akan tetapi pengaruh pemilihan susunan serat sebagai bagian penguat material komposit juga merupakan hal yang penting yang harus diperhatikan selain diameter pahat.

Tabel 6. Hasil ANOVA data pengukuran delaminasi pada lubang permukaan bawah (exit)

\begin{tabular}{lcccccc}
\hline Parameter & DF & $\begin{array}{c}\text { Seq } \\
\text { SS }\end{array}$ & $\begin{array}{c}\text { Adj } \\
\text { SS }\end{array}$ & $\begin{array}{c}\text { Adj } \\
\text { MS }\end{array}$ & F & P \\
\hline $\begin{array}{l}\text { Dia. Pahat } \\
(\mathrm{mm})\end{array}$ & 2 & 0,045 & 0,045 & 0,022 & 3,57 & 0,037 \\
$\begin{array}{l}\text { Feeding } \\
(\mathrm{mm} / \mathrm{r})\end{array}$ & 2 & 0,029 & 0,029 & 0,014 & 2,32 & 0,110 \\
$\begin{array}{l}\text { Sudut ujung } \\
\left(2 \kappa_{\mathrm{r}}, \mathrm{o}\right)\end{array}$ & 2 & 0,026 & 0,026 & 0,013 & 2,11 & 0,133 \\
& & & & & &
\end{tabular}




\begin{tabular}{lcccccc}
$\begin{array}{l}\text { Susunan } \\
\text { serat }\end{array}$ & 2 & 0,044 & 0,044 & 0,022 & 3,54 & 0,038 \\
Pendingin & 2 & 0,062 & 0,062 & 0,031 & 4,96 & 0,011 \\
Error & 43 & 0,268 & 0,268 & 0,006 & - & - \\
Total & 54 & 0,474 & - & - & - & - \\
\hline
\end{tabular}

Kesimpulan yang ditarik dari hasil ANOVA dapat dipertanggungjawabkan. Hal ini disebabkan oleh tidak adanya faktor yang meragukan dari nilai residual yang ditampilkan pada Gambar 9. Walaupun tampilan Histogram dari nilai residual tidak seutuhnya seimbang. Akan tetapi kondisi ini tidak menjadi indikasi adanya kesalahan (outliers) maupun kecenderungan miringnya dari distribusi data (skewness).

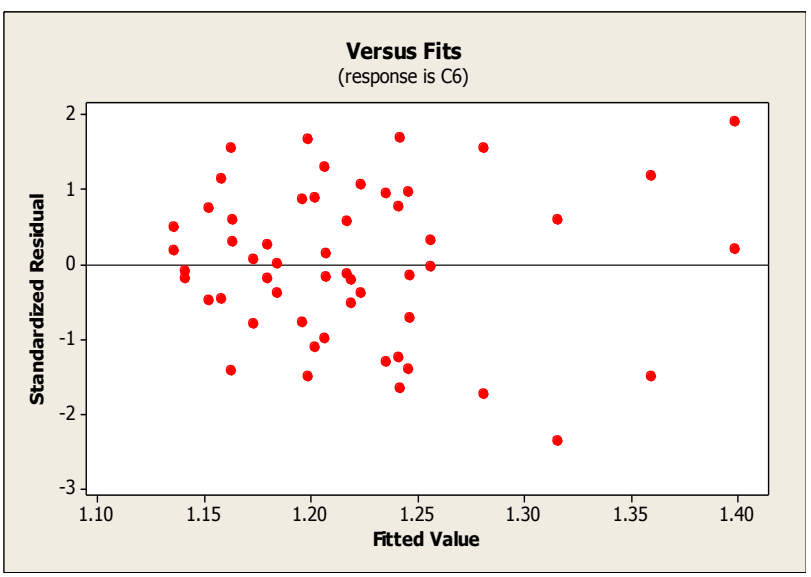

(a)

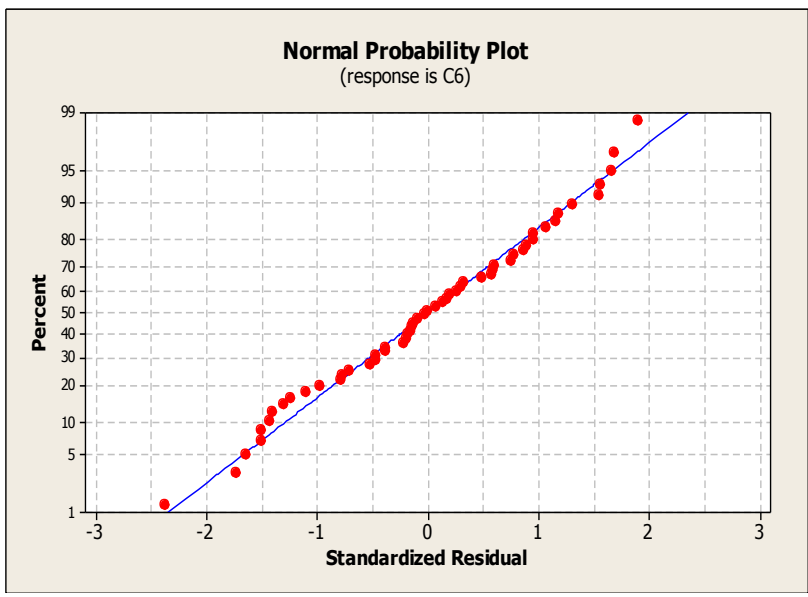

(b)

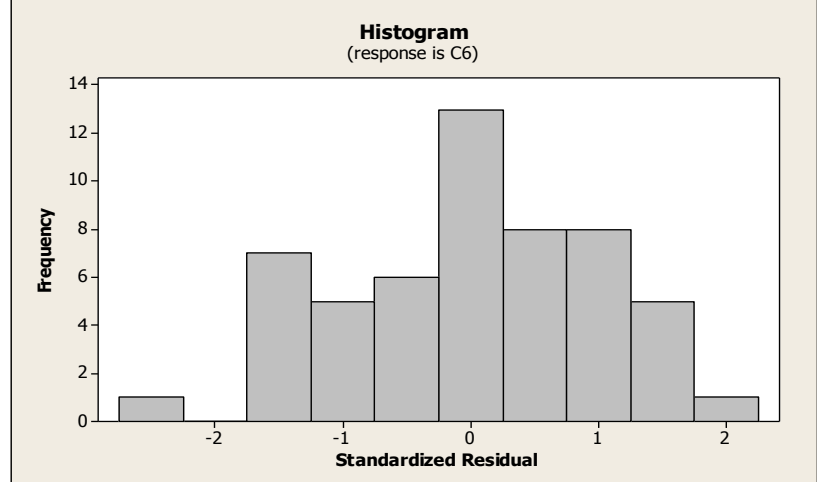

(c)

Gambar 9. Hasil analisa normality data pengujian untuk data delaminasi lubang masuk (entrance)

\section{KESIMPULAN DAN SARAN}

Penelitian untuk mengetahui pengaruh penguatan komposit serat nanas terhadap kemungkinan terjadinya delaminasi pada proses pembuatan lubang telah dilakukan. Untuk itu ada beberapa kesimpulan yang dapat ditarik, yaitu:

1. Pada bagian permukaan lubang, terjadinya delaminasi tidak dipengaruhi oleh jenis pemilihan dari susunan serat nanas. Akan tetapi untuk penyelesaian lubang, pemilihan susunan serat nanas yang tepat akan dapat mengurangi kemungkinan terjadinya delaminasi.

2. Secara umum yang berperan penting terhadap kemungkinan terjadinya delaminasi adalah parameter yang memiliki kontribusi terhadap kemampuan pahat untuk melakukan penetrasi ke dalam material komposit. Yang dalam hal ini ada diameter pahat dan pelumasan yang dilakukan oleh cairan pendingin yang dipilih.

3. Walaupun cara menyusun serat sebagai penguat pada material komposit akan meningkatkan sifat mekanikanya, akan tetapi tidak menjamin mampu mesin material komposit tersebut juga akan meningkat.

\section{UCAPAN TERIMA KASIH}

Pada kesempatan ini penulis mengucapkan terima kasih kepada Jurusan Teknik Mesin Fakultas Teknik Universitas Andalas yang telah membiayai penelitian ini melalui RKAKL TA 2017 dengan nomor kontrak: 060/UN.16.09.D/PL/ 2017 Tanggal 4 Juli 2017. 


\section{DAFTAR PUSTAKA}

[1] S.R. Ravishankar, C.R.L. Murthy, "Modeling drill induced delaminations in composite laminates", in: Proceedings of 14th World Conference on Non-Des-tructive Testing, vol. 2, Oxford and IBH Publishing, 1996. pp. 489-494.

[2] H. Hocheng, and C.C. Tsao, "Effects of special drill bits on drilling-induced delamination of composite materials", International Journal of Machine Tools \& Manufacture, vol 46. Pp 1403-1416, 2006.

[3] T.L. Wong, S.M. Wu and G.M. Croy, "An analysis of delamination in drilling composite materials", in: Proceedings of 14th SAMPE Technology Conference, Atlanta, GA, USA, 1982, pp. 471-483.

[4] E. Persson, I. Eriksson and L. Zackrisson, "Effects of hole machining defects on strength and fatigue life of composite laminates", Composites Part A, vol 28, no. 2, pp 141-151, 1997.

[5] H. Hocheng and C.C. Tsao, "Effects of special drill bits on drilling-induced delamination of composite materials", International Journal of Machine Tools \& Manufacture, vol 46. Pp 1403-1416, 2006.

[6] R.H. Kirby, Vegetable Fibres, Hand Books, ed., Leonard Hill, London, 1963.
[7] D.P. Setyawan, H.N. Sari and P.D.G. Pertama , "Pengaruh Orientasi Dan Fraksi Volume Serat Daun Nanas (Ananas Comosus"), 2012.

[8] N.D. Shaheb and J.P. JOG, Natural Fiber Polymer Composites: A Review, Polymer Engineering Group, Chemical Engineering Division, National Chemi-cal Laboratory, Pune 411 008, India, 1999.

[9] L.M. Durão, A.G. Magalhães, J.M.R.S. Tavares and A.T. Marques, "Ana-lyzing objects in images for estimating the delamination influence on load car-rying capacity of composite laminates", Instituto de Engenharia Mecânica e Gestão Industrial, Faculdade de Engenharia da Universidade do Porto /Departamento de Engenharia Mecânica e Gestão Industrial, PORTO, Portugal, 2008

\section{NOMENKLATUR}

$\mathrm{F}_{\mathrm{d}} \quad$ Rasio Delaminasi

$\mathrm{D}_{\max } \quad$ Nilai Delaminasi

D Diameter nominal lubang 